
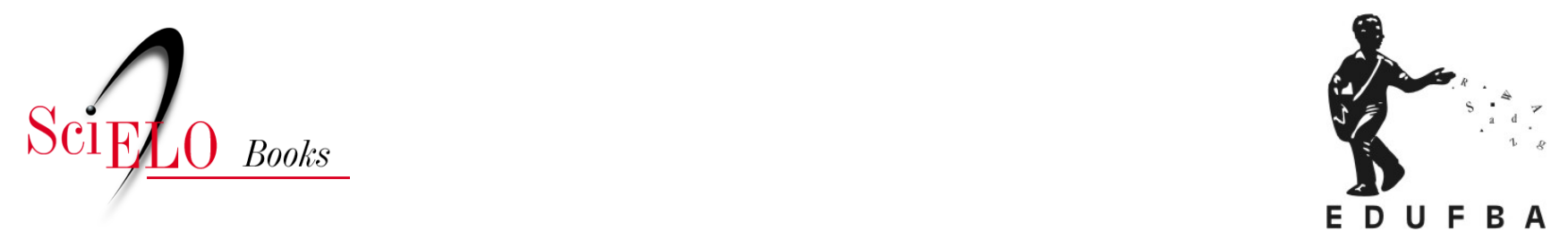

\title{
"O jogo tá pegado" \\ times e campeonatos de futebol com jogadores usuários de crack na região central da cidade de São Paulo
}

\author{
Ygor Diego Delgado Alves
}

\section{SciELO Books / SciELO Livros / SciELO Libros}

ALVES, Y.D.D. "O jogo tá pegado": times e campeonatos de futebol com jogadores usuários de crack na região central da cidade de São Paulo. In: Jamais fomos zumbis: contexto social e craqueiros na cidade de São Paulo [online]. Salvador: Edufba: Cetad, 2017, pp. 275-324. Drogas: clínica e cultura collection. ISBN: 978-85-232-1859-1. https://doi.org/10.7476/9788523218591.0008.

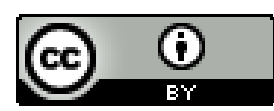

All the contents of this work, except where otherwise noted, is licensed under a Creative Commons Attribution $\underline{4.0 \text { International license. }}$

Todo o conteúdo deste trabalho, exceto quando houver ressalva, é publicado sob a licença $\underline{\text { Creative Commons }}$ Atribição 4.0. 


\section{"O JOGO TÁ PEGADO": TIMES E CAMPEONATOS DE FUTEBOL COM JOGADORES USUÁRIOS DE CRACK NA REGIÃO CENTRAL DA CIDADE DE SÃO PAULO}

Um lema marcou a prevenção ao abuso de drogas na década de 1980: "Esporte não é droga. Pratique." Esta visão possivelmente se associava ao caráter disciplinar das práticas esportivas caudatárias do ocaso do Regime Militar. No findar desta década, Carvalho \& Carlini-Cotrim (1992) fizeram uma ampla pesquisa entre estudantes de ensino fundamental e médio de 15 capitais brasileiras sobre a prática de atividades não curriculares e o consumo de álcool e drogas; não encontraram nenhuma associação entre a diminuição deste consumo e a prática de esportes, artes e atividades comunitárias. A única correlação negativa perfeita foi obtida entre participantes em atividades sindicais na cidade de Salvador. A ideia central das campanhas que vinculavam a prática desportiva com a diminuição do consumo de álcool e outras drogas era a de se "tirar os jovens do ócio e das ruas", porém, para as autoras “[...] conceber o tempo livre como propiciador de comportamentos de risco" [...] implicaria "na identificação do estudante pobre, que gasta seu tempo livre nas ruas, como um sujeito potencialmente drogado". (CARVALHO; CARLINI-COTRIM, 1992, p. 147) Não se trata, para as autoras, de se ocupar o tempo de modo não voluntário como forma de prevenção ao abuso de drogas, mas de se:

[...] deslocar a discussão do 'fazer x não fazer' para a do como fazer, tendo como pressuposto que um jovem realizado em suas potencialidades (e não apenas ocupado, ou assimilando padrões e códigos) deve ser a meta adequada de programas que visem à saúde mental do adolescente. A ânsia de ocupar o jovem a qualquer custo passa, nesta perspectiva, a ser substituída pela preocupação com a qualidade - em termos de vivência, criatividade, espaço para questionamento que atividades não curriculares 
possam vir a oferecer. (CARVALHO; CARLINI-COTRIM, 1992, p. 148-149)

Não trataremos, neste capitulo, de prevenção ao abuso de drogas, mas do trabalho com usuários em oficinas de futebol. Porém, a pesquisa de Carvalho e Carlini-Cotrim (1992) nos é útil para evitarmos uma visão instrumental e ingênua do esporte como instrumento de prevenção, ou no nosso caso, porta de saída do uso abusivo de drogas, mais especificamente o crack. Veremos aqui, a partir da descrição proporcionada pela pesquisa etnográfica, como o futebol, e particularmente os sentimentos de equipe possibilitados pela absorção no jogo, o enquadramento e as regras de irrelevância, dá oportunidade para o trabalho do orientador socioeducativo - aqui designado pela denominação utilizada pelos nossos interlocutores "professor" - abrir espaço para um aumento do autocontrole por parte dos jogadores sobre seu padrão de uso de álcool, crack e outras drogas devido a mudanças em sua estrutura de vida. ${ }^{122}$

Cinco jogadores uniformizados de cada lado e um juiz, numa quadra coberta de futebol de salão. Nas laterais do campo, o técnico grita frases de orientação tática e técnica: "Sai da marcação"; "Vem, vem, vem"; "Espalha aí, vamos jogar aberto"; "Ó a marcação aí, ó". Determinado momento, resolve orientar de modo individualizado: "Levanta a cabeça, Paraná"; em outro, de modo um pouco mais incisivo: "Vamos fazer gol, caralho!". Nada que não possa ser encontrado em uma escolinha de futebol, ou em um colégio durante a aula de educação física. Porém, quem admirasse a partida poderia perceber alguns aspectos intrigantes no desenrolar das jogadas. A primeira delas é o fato do técnico ser responsável por ambas equipes em campo, durante este jogo/treino. Até este ponto, nada haveria de tão extraordinário, mas, talvez a presença de um jogador trajando boné, óculos escuros e fones de ouvido fosse algo a

122 Aqui entendida segundo as pesquisas de Grund (1993). 
despertar maior curiosidade. Mais ainda, se este jogador perdesse a oportunidade de marcar um considerável número de gols por, aparentemente, procurar dar a eles um tom a mais de brilho, um toque a mais de plasticidade, de beleza e mesmo certo "quê" de comicidade, isto causaria ainda mais interesse no observador. Este jogador é Paraná, constantemente advertido pelo "professor" quanto a sua postura corporal. Em breve veremos porque Paraná nos é tão importante.

Ainda assim, a singularidade desta partida está longe de ser desvendada. Para tanto, precisariamos fazer um duplo movimento. Um para fora e outro no sentido inverso. O primeiro nos mostraria o contexto no entorno da quadra de futebol e o segundo, quem eram aqueles jogadores minutos antes do início da partida e como estão após seu término. A quadra se situa em um centro de acolhida conveniado com a Prefeitura do Município de São Paulo, no bairro do Bom Retiro e é cercada por símbolos do cristianismo católico. Paraná é um ex- "pai de rua", termo conotativo daqueles responsáveis por algum tipo de atividade, muitas vezes ilegal, no ambiente das ruas e, geralmente, com sua autoridade imposta pela violência.

Ainda não é este o aspecto capaz de causar maior impressão naquele disposto a aproximar-se um pouco mais do cotidiano destes jogadores, este observador atento teria oportunidade de saber do uso cotidiano de crack pela quase totalidade dos envolvidos, inclusive Paraná. Assim como, por mais de uma década, também pelo técnico ou professor, um ex-usuário de crack e ex-morador de rua na região do centro da cidade de São Paulo, conhecida como Cracolândia. Um observador participante, caso desejasse mostrar suas habilidades em campo, ou simplesmente divertir-se em uma partida/treino de futebol com 10 minutos de duração ou dois gols marcados pela mesma equipe, correria o risco de sentir nas próprias canelas o ímpeto e vontade de vencer presente dentro daquelas quatro linhas. Nas palavras de Johan Huizinga "O que é primordial é o desejo 
de ser melhor que os outros [...] o principal é ganhar". (HUIZINGA, 1996, p. 58)

Vimos acima, uma breve introdução à nossa pesquisa de campo e a ela retornaremos muitas vezes mais. Porém, se faz oportuno iniciarmos abaixo nossa entrada numa das bases teóricas deste capítulo.

\section{Fun in games}

Erving Goffman e Robert McGinnis publicaram em 1961, um livro com dois estudos intitulado Encounters: two studies in the sociology of interaction. O trabalho que particularmente nos interessa nesta obra é Fun in games. O paper versa sobre quão longe alguém pode ir por tratar a diversão seriamente. Como supracitado, não obstante as brincadeiras de Paraná, o jogo é "pegado". ${ }^{123}$ Para estes autores, os jogos são um tipo específico de encontro focado; envolvem um foco visual e cognitivo único de atenção. Enquanto estão na quadra, Paraná e demais jogadores encontram-se imersos em um ambiente capaz de intensificar a relevância mútua de seus atos, assim como de maximizar a oportunidade de cada participante perceber o monitoramento do outro sobre ele. "Jadiel pipoqueiro!", grita um jogador irritado com certo tipo característico de comportamento em campo, marcado pela perceptível falta de comprometimento em participar ativamente das jogadas mais duras. "O cara tá cobrando lateral com a bola rolando", protesta certo jogador ao ver outro, da equipe adversária, desrespeitar uma regra básica do futebol de salão. "Não pode sair assim", do professor a um jogador que abandona o treino em andamento.

Este monitoramento promove uma abertura mútua à comunicação e possibilita a emergência de um "nós racional" (GOFFMAN; MCGINNIS, 1961, p. 18) como um senso de coi-

123 Termo êmico utilizado para designar uma partida muito disputada de futebol. 
sa única que "nós" estamos fazendo naquele momento. Além disto, tanto quanto estes encontros focados consigam prover a base de comunicação para um fluxo circular de sentimentos entre os participantes, conseguirão dispor a eles compensações corretivas para atos desviantes. "Cada um no seu, cada um no seu. Tem dois caras sobrando aqui (sem marcação)", diz um jogador ao time.

Vamos falar um pouco de Maradona, um acolhido ${ }^{124}$ e participante da oficina de futebol, também ex-jogador profissional de pequenas equipes da região de Sorocaba, cidade próxima a capital paulista. Ele chegou a jogar com o jovem jogador profissional de fama internacional, Robinho, antes deste se tornar craque da equipe do Santos F. C. Maradona, certo treino, apresentou-se "cheiradaço", nas palavras do professor e logo ao iniciar a primeira partida daquela tarde, ele lhe chama a atenção. Assim, Maradona permanecerá recebendo comentários sobre seu estado e de como está prejudicando sua equipe até o fim da segunda partida e também coincidentemente ou não, de sua segunda derrota. "Deixou seu time na mão, hein, Maradona", brada o professor após levantar a camisa dele e comentar sua magreza, mesmo tendo o jogador convertido um gol de pênalti. Sobre o comportamento da equipe com Maradona, o professor observa: "Os caras mesmo cobram dele". Coincidentemente, naquele exato momento, ao lado da quadra, Maradona realmente era chamado à atenção. Goffman e McGinnes (1961) devotam especial atenção aos adictos, ou usuários de álcool e drogas e sua possível dificuldade em manejar seu estado de modo discreto quando sob efeito destas substâncias, sem contagiar as obrigações de interação para que o encontro focado, como é o caso da partida esportiva, possa manter sua fronteira.

124 Termo técnico utilizado pelos orientadores socioeducativos e demais profissionais dos equipamentos destinados a abrigar a população em situação de rua para referir-se a esta população quando atendida. Para aqueles usuários apenas dos serviços da Tenda, o termo utilizado é convivente. 
Voltemos a Paraná, o ex-pai de rua, veremos agora como certas propriedades dos participantes, como ser ex-pai de rua, serão tratadas pelas regras de irrelevância como se não estivessem presentes. Uma atividade engajadora como é o jogo de futebol em geral e particularmente entre nossos interlocutores é capaz de agir como uma fronteira em torno dos participantes, vedando-os dos muitos mundos potenciais de significado e ação. Sem esta barricada abrangente, presumivelmente, os participantes estariam imobilizados por uma inundação de bases para a ação. Em um encontro focado, como são os jogos de futebol, as regras de irrelevância nos falam sobre aquilo a ser ignorado e por consequência o que deve ser tratado como real. Elas tornam possiveis uma matriz de acontecimentos relevantes, ou eventos ligados ao jogo, envolvidos em um esquema de expressão e interpretação, assim como possibilita papéis e identidades geradas pelo jogo. Desta maneira, Maradona não poderia invocar sua condição de ex-jogador para ser escalado em um campeonato, sua antiga condição e qualquer importância dada a ela é irrelevante frente ao mau desempenho em campo.

Mesmo o professor ${ }^{125}$ é cobrado de acordo com o papel exercido na partida e caso esteja como juiz ou treinador poderá ser questionado ou chamado à atenção. Maradona, ao constatar a segunda derrota de seu time acusa o juiz/professor de ter "roubado". Em outra oportunidade, ao comentar a escalação para um campeonato no qual participaram equipes de acolhidos, de conviventes e de orientadores socioeducativos, Maradona questiona os critérios adotados na montagem das equipes: "Na cabeça dele de técnico, ele pensou que iria fazer o nome com o outro time e deixou nóis [sic] sem reserva". Ainda em outra

125 Colocado nesta posição por ser orientador socioeducativo em um equipamento público voltado à sociabilidade da população de rua, oficialmente designado como Tenda e por ter escolhido o futebol como recurso de trabalho com esta população. 
circunstância ao conversar distraidamente comigo, o professor é advertido por um jogador em campo, de estar demasiadamente absorto pela nossa conversa e não com o desenrolar dos acontecimentos da partida. Ele recebe o aviso: "Você não está vendo o jogo, não?”. O juiz, certamente é um recurso percebido, ou seja, para Goffman e McGinnes (1961), ele faz parte dos eventos e papéis percebidos localmente, como também são os papéis de técnico e jogador.

Paraná, quando não está jogando futebol de salão é pai de rua $^{126}$, mas dentro de quadra é um jogador alegre dado a enfeitar suas jogadas. Depois de desperdiçar algumas oportunidades, seu gol é especialmente comemorado pelos colegas. Em outra ocasião, ao término de uma série de partidas/treino, ele chega a declarar com uma "alegria insopitável e gratuita" (RODRIGUES, 1994, p. 80) e afirma que: "Hoje foi bom demais. Nós viemos pra brincar". O jogo permite a expressão de uma faceta jocosa, por certas vezes ele não ser tão "pegado" assim. ${ }^{127} \mathrm{Na}$ ocasião da frase acima, dita por Paraná, os gols sequer foram contados. Além disto, por não ser o jogo semelhante à rua, as regras de irrelevância ${ }^{128}$ não permitem às maneiras de pai de rua furar a barreira e adentrar na quadra. Possivelmente por esta razão, Paraná seja considerado o jogador exemplo pelo professor. Antes de começar a jogar futebol, "criava problema e arranjava briga no albergue”. As regras de irrelevância obrigaram, ou criaram a possibilidade para que, no jogo, o ex-pai de

126 Paraná era líder de uma "maloca", nome dado ao tipo de moradia assemelhada ao cortiço, com dezenas de pessoas ligadas a ele. Certo dia envolveu-se com a esposa de um rapaz recém preso e foi expulso violentamente.

127 Não é em qualquer ocasião que esta condescendência está presente. Em outro treino com jogos mais "pegados", um jogador que tentou fazer gols com excesso de dribles foi ridicularizado como "Neymar do crack", "Neymar do tráfico" e "Neymar do fluxo".

128 As regras de irrelevância permitem o enquadramento pelo jogo dos aspectos apropriados da realidade e o descarte dos demais, assim como parece existir para deixar algo dificil ser silenciosamente expresso tanto quanto ser totalmente excluído da cena. 
rua transmutado em jogador demonstre, sob o monitoramento e sanção da equipe, apenas seus atributos ligados à diversão, ou ao bom desempenho do time. Os modos de pai de rua não ajudam a marcar gols e o jogo de futebol compreende uma gama de situações dificeis que cada jogador estará sob risco de encarar. Também demanda as qualidades de mente e corpo que ele precisará para enfrentar bem estas situações. Por isto, é apenas no futebol, por exemplo, que "o zagueiro tem que ter o tempo da bola” (CAVALCANTE, 2011, p. 98), estas qualidades chegam a estar descritas nos manuais de educação física. ${ }^{129}$ Desta maneira, o jogo de futebol parece encaixar-se nestas observações feitas por Goffman e McGinnes (1961) sobre encontros focados como algo destacado da vida ordinária.

Uma matriz de possíveis eventos e um elenco de papéis por cuja sanção o decorrer dos eventos constitui em conjunto um campo para uma fatídica ação dramática, um plano de existência, uma máquina de significado, um mundo nele mesmo, diferente de todos os outros mundos exceto os outros gerados quando o mesmo jogo é jogado novamente. (GOFFMAN; MCGINNIS, 1961, p. 26-27, tradução nossa)

Percebemos então, como o futebol consegue gerar um mundo diferente do mundo da rua e do uso do crack, mesmo tendo jogadores daí advindos. Seus "movimentos corporais performados localmente" (GOFFMAN; MCGINNIS, 1961, p. 28) são enquadrados pelo jogo e caso não sejam apropriados são descartados da realidade pelas regras de irrelevância, quase como uma corporalidade enquadrada.

Os jogos nos separam da vida ordinária e nos imergem em mais uma de suas possibilidades, eles nos dão a chance de

129 "Os zagueiros centrais (ou zagueiros de área). Física: Estatura elevada, agilidade, força, impulsão, bom porte físico, equilíbrio, reação rápida. Psicológicas: capacidade de liderança, coragem, calma, muita decisão, combatividade, maturidade”. (BOSARI, 1989, p. 15) 
vivermos outras realidades nas quais eventos visiveis irrelevantes serão ignorados; assuntos privados irrelevantes serão mantidos fora da mente e uma inconsciência sem esforço poderá se apoderar de nós. (GOFFMAN; MCGINNIS, 1961) A perspectiva de jogo reduz a situação a times, um lado do qual passamos a ser o jogador, um agente do jogo que age e faz, não para uma individualidade, mas para uma equipe com quem se compartilha uma identidade de interesse. A atividade básica de um jogo é o movimento, cada um selecionado entre limitado número de possibilidades e sendo largamente determinado pelo movimento prévio do time oponente. O conceito de interação é assim transformado, para Goffman e McGinnis (1961) refere-se agora a uma forma altamente estruturada de destino mútuo.

Este destino mútuo pode ser percebido nas orientações e admoestações do professor referindo-se a comportamentos pouco producentes em campo, mas aparentemente, além disto, inadequados a um ambiente quase familiar: "Vamos parar de xingar aí e jogar mais futebol". Ou, ao ter de dar socorro a um jogador objeto de uma falta mais dura: "Devagar aí, tamo [sic] em família".

O envolvimento completo produzido pelo jogo, apesar de sua trivialidade, pode transformar qualquer participante em um antagonista digno, malgrado grandes diferenças de status social e das possiveis reivindicações de prestígio advindas de outras realidades sociais. (GOFFMAN; MCGINNIS, 1961) A história do futebol no Brasil é a própria confirmação desta idéia. No início do século XX, o futebol se tropicalizava no Rio e em São Paulo, deixava de ser privilégio de jovens abastados e satisfeitos em copiar o estilo inglês de jogar para ser "fecundado pela energia criadora do povo que o descobria". (GALEANO, 1995, p. 39) Os usuários de crack também encontraram no futebol e na disputa de campeonatos, oportunidade de, uniformizados e com o desempenho enquadrado pelo jogo, serem reconhecidos socialmente. 
O envolvimento é uma possibilidade aberta pelo jogo. O monitoramento mútuo objetiva impedir o livre desenvolvimento da jogada pelo adversário e promover o jogo realizado pela própria equipe. Faz deste envolvimento, uma obrigação a ser sustentada em dada medida; nem exageradamente, nem pouco. Ademais, este envolvimento espontâneo compartilhado em uma atividade mútua coloca os parceiros em algum tipo de solidariedade exclusiva e permite a eles expressar companheirismo, proximidade psíquica e respeito mútuo; a falha em participar de boa vontade pode ser interpretada como expressão de rejeição aos presentes ou ao contexto. (GOFFMAN; MCGINNIS, 1961) Não seriam então, sem motivo as declarações de um usuário de crack sobre sua antiga equipe do albergue: ${ }^{130}$ "O time faz a gente gostar mais um do outro. Quando alguém fazia dívida, a gente ia lá e pagava. Eu não usava drogas naquela época e sobrava um dinheirinho com que eu comprava refrigerante pra todo mundo [...] um aprende a respeitar mais o outro". Enfim, é o envolvimento de outras pessoas, apesar do possível vazio de interesse de alguém, o fiador da absorção.

Ademais, parece não haver agente mais efetivo que outra pessoa para tornar um mundo vivo para alguém ou, por uma olhada, um gesto, ou uma observação, ativar a realidade em que alguém esteja alojado. É somente nos encontros face a face que quase tudo pode vir a ser base de uma perspectiva e definição de uma situação. (GOFFMAN; MCGINNIS, 1961, p. 41)

Para Goffman e McGinnes (1961), em uma teoria do jogo, a mais importante propriedade do ponto de vista da interação é a

130 O grupo passou a ter dificuldade em unir a equipe para os treinos e chegou ao fim com a mudança de jogadores que saíam do equipamento público destinado a abrigar a população em situação de rua. Este mesmo usuário acabara de formar-se no Programa Nacional de Acesso ao Ensino Técnico e Emprego (Pronatec) e estaria dando início em um emprego para trabalhar com reciclagem em uma grande rede de supermercados, naquela semana, primavera de 2013. 
"natureza psicobiológica orgânica do envolvimento espontâneo" (GOFFMAN; MCGINNIS,1961, p. 38), o engajamento espontâneo do indivíduo em uma atividade capaz de produzir certa empolgação apropriada a conduzi-lo para uma absorção visual e cognitiva e, por uma inatenção seletiva, à despreocupação com eventos outros que não a atividade. O participante torna-se, assim, parte integral de uma situação governada tanto pelas regras do jogo, ${ }^{131}$ quanto pela estrutura do encontro. Esta estrutura é responsável pela automobilização através da qual o movimento enquadrado pelas regras é executado. Para aprender sobre a estrutura dos encontros focados podemos examinar o que acontece quando seu ordenamento é quebrado e como certa definição da situação exclui determinadas perspectivas quando é satisfatoriamente sustentada.

Os encontros face a face possibilitam a um não humano, como o apito do professor/juiz, definir circunstâncias de plena absorção pela situação do jogo, como uma falta ou um gol anulado. "Pessoal, vamos ouvir o apito", grita constantemente o professor ao fazer as vezes de juiz em um treino. Em determinado momento, ele vira em minha direção e comenta: "Cara, você não faz ideia do que o apito significa para eles em termos de autoridade, limite".

O material esportivo, no qual se incluem os uniformes, ficam também sujeitos às regras que estruturam o jogo, segundo Goffman e McGinnes (1961). Os uniformes são parcela importante do esforço por um disfarce próprio ao encontro focado e distinto da seriedade da vida. Os significados relevantes ao jogo das várias peças do equipamento são neles mesmos um disfarce útil. Assim sendo, por detrás destes significados, os valores sentimentais, materiais e estéticos das peças podem atuar dentro da interação com tons de significado que nada tem a ver com a lógica do jogo, mas relacionadas com o prazer do encontro. Igualmente, a maleabilidade dos arranjos de

131 Veremos abaixo, como as regras do jogo também podem ser manipuladas. 
jogo - escolha dos jogos, lados, dificuldade, apostas - permite a fabricação da quantidade certa de disfarce e uma descontinuidade com o mundo é alcançada mesmo quando uma conexão com ele é estabelecida.

Não obstante o envolvimento de outras pessoas no jogo, a percepção que algum participante não está espontaneamente envolvido na atividade mútua pode desacreditar a identidade imputada a ele como alguém capaz e pronto para imergir-se em um encontro, assim como pode enfraquecer, do ponto de vista dos demais envolvidos, sua própria absorção no encontro e a crença na realidade do mundo prescrito. Um desvio percebido da norma pode ainda ter um efeito "multiplicador", infectando todo encontro.

A organização do encontro fornece as concepções dos participantes concernentes a sua identidade, assim como a toda identidade da ocasião social da qual o encontro é visto como parte. (GOFFMAN; MCGINNIS, 1961) Veremos abaixo, como a sobreposição da identidade de "vapor" e a de goleiro, trazida a tona por um evento do jogo, pode colocar em xeque o eixo organizacional do encontro. As identidades organizadoras da interação são ameaçadas de serem desacreditadas ou suplantadas pelos problemas causados por certos eventos que não acrescentam meramente um ruído disruptivo. Mesmo considerando, com Goffman e McGinnes (1961), que de todas nossas capacidades, aquela para envolvimento espontâneo parece ser a menos sujeita a controle consciente. Tais eventos, ainda que pequenos, podem enfraquecer todo o desenho do encontro, deixando os participantes confusos sobre o que fazer a seguir, ou o que tentar ser posteriormente. Veremos a seguir como em um encontro de equipes de futebol de diversas Tendas, ${ }^{132} \mathrm{um}$

132 Tendas são os espaços de convivência e atendem: [...] a função de "porta de entrada" que possibilite o atendimento às necessidades básicas da pessoa em situação de rua e vulnerabilidade social como higiene pessoal, oferecendo banhos, cortes de cabelo, lavagem de roupas, atendimento com assistentes sociais, psicólogos e encaminhamentos das diversas deman- 
evento pôde colocar em risco a identidade dos participantes, as barreiras a bens externamente percebidos e até o próprio encontro.

\section{Um "incidente"}

Incidentes são aqui entendidos como os episódios capazes de ameaçar, pelo conflito, o enquadramento do encontro. "Durante um encontro, eventos podem ocorrer, tanto intencionais ou não, que repentinamente aumentam o nivel de tensão". (GOFFMAN; MCGINNIS, 1961, p. 45) O Intertendas é um campeonato e reúne times de acolhidos e de funcionários. ${ }^{133}$ Acolhido, como vimos, é o termo nativo e "técnico" para designar aqueles hóspedes ${ }^{134}$ em algum equipamento público municipal ou conveniado dedicado a abrigar a população em situação de rua. São os participantes do encontro, pessoas pertencentes à parcela da população de rua frequentadora de alguma oficina de futebol sob responsabilidade de um orientador socioeducativo. Este é contratado pela entidade gestora do equipamento sem concurso público e, portanto, não faz parte dos quadros estáveis do funcionalismo. Também participam times de orien-

das que ali cheguem. É um equipamento da rede sócio assistencial que permite ao individuo a oportunidade de reestabelecer seus vinculos antes fragilizados ou rompidos [...] Desta forma, o orientador socioeducativo presente em todas essas dinâmicas, faz dessa relação, instituição-população, uma relação pautada pela horizontalidade, pelo vinculo, que rompe com o distanciamento conservador, moralista e excludente, potencializando a relação de aproximação, de igualdade, de força de vontade e mais ainda da perspectiva de saída, do processo de institucionalização, saída reintegrativa, emancipada e autônoma. (COMPLEXO PRATES, 2014)

133 Entendemos como funcionários, os orientadores socioeducativos.

134 Ao observador não pertencente à área do serviço social, o uso do termo "acolhido" não apenas pelos funcionários, mas como termo técnico, correto e oficial, soa como pertencente a uma lógica caritativa. A instituição acolhe, o hotel hospeda. Na rede hoteleira, o hóspede paga, escolhe e decide, em uma lógica de prestação de serviço. Nos Centros de Acolhida não há instâncias locais formais de participação, de fato, dos atendidos, nem na gestão dos equipamentos, tão pouco na fiscalização dos gastos executados com as verbas municipais que os mantém. 
tadores socioeducativos dos equipamentos públicos dedicados à população em situação de rua. Tanto funcionários quanto acolhidos, porém, com maior intensidade os últimos, circulam pelos diversos equipamentos, travando ai, relações sociais relativamente duradouras e por vezes conflituosas. A quase totalidade dos acolhidos e conviventes envolvidos nas oficinas de futebol são usuários de crack, segundo informação dos orientadores socioeducativos; confirmada pela pesquisa de campo.

Os conviventes e acolhidos haviam participado de ao menos uma reunião de preparação do Intertendas, ${ }^{135}$ porém, a montagem das chaves com a ordem dos confrontos foi feita apenas momentos antes da primeira partida, por sorteio. Este processo leva algum tempo, assim como o atrazo de algumas equipes fazem com que muitos jogadores fiquem ansiosos, portanto, o primeiro jogo começa tenso e muito disputado. Os orientadores socioeducativos dirigem suas equipes, mas isso não impede a ocorrência de um conflito nos primeiros instantes da partida inicial, impondo a intervenção dos orientadores e do juiz. Este último, tão pouco é funcionário de carreira do município, mas nos dizeres de um orientador é "um batalhador pelo esporte".

A primeira partida é entre equipes de acolhidos e conviventes. As cobranças sobre a defesa do time que se encontra em desvantagem no início do segundo tempo são grandes. O campeonato é disputado em partidas de dois tempos de 15 minutos. Uma das equipes está particularmente nervosa e um jogador precisa ser contido pelo orientador socioeducativo/professor. ${ }^{136}$ A seguir, em uma jogada mais dura, este jogador nervoso desde o início da partida inicia uma discussão acalorada com o goleiro Ronaldo da equipe adversária e o leva (Ronaldo) à expulsão. Ouço de um participante torcedor ao meu lado:

135 Nome dado aos campeonatos de futebol que reúnem times dos centros de acolhida e de convivência municipais.

136 Impressiona-me o fato de o juiz apitar com um copo de água na mão. 
“O jogo tá pegado, ${ }^{137}$ hein mano?". No momento da confusão todas as equipes interviram, a comoção foi geral. No decorrer da partida, dois jogadores da reserva são advertidos pelo juiz e ameaçados de serem expulsos caso não cessem de "tentar apitar o jogo". Nos próximos jogos, o papel de juiz será desempenhado também pelo motorista de uma das Kombis responsáveis pelo transporte, assim como por funcionários e orientadores socioeducativos. ${ }^{138}$ Durante os intervalos do jogo, os orientadores socioeducativos dão orientações técnicas aos seus jogadores. No decorrer das partidas, o goleiro expulso no primeiro jogo pôde voltar a atuar por outras equipes. Suas boas defesas são comemoradas com aplausos de sua equipe e da torcida em volta da quadra.

Uma disputa para semifinalista é feita nos pênaltis e Ronaldo fez grandes defesas, além de marcar vários gols cobrando pênaltis. Como o empate permanece após todos os jogadores dos dois times terem batido seus pênaltis, novas regras são acordadas $^{139}$ a cada novo empate, até o ponto de Ronaldo bater pênaltis seguidos. Ele é o grande responsável pela vitória de uma equipe de acolhidos. Enquanto os pênaltis são cobrados, as funcionárias do albergue deixam suas atividades de trabalho e juntam-se ao encontro como torcedoras do time da casa. As funcionárias da cozinha abandonam seus afazeres e dirigem-se uniformizadas à quadra para torcer. No decorrer dos jogos, não foi incomum jogadores atuarem em mais de uma

$137 \mathrm{Ou}$ absorvente como diriam Goffamn e McGinnes, ou ainda Clifford Geertz sob sua influência. (GEERTZ, 1989)

138 Pudemos perceber, entre os que trabalham com a população em situação de rua, certa visão sobre seu papel em contato direto com os acolhidos nas dependências dos equipamentos públicos e conveniados. Embora o cargo de orientador socioeducativo apareça ligado, particularmente, aos serviços destinados ao atendimento de jovens, adultos e idosos (SECRETARIA MUNICIPAL DE DESENVOLVIMENTO E ASSISTÊNCIA SOCIAL, 2010), o termo orientador socioeducativo é comumente atribuído a todos os funcionários não técnicos com trabalho diretamente ligado aos usuários destes serviços.

139 Discutiremos abaixo, como estas regras são manipuladas. 
equipe e enquanto esperam sua vez de jogar, muitos aproveitam para almoçar.

O professor cujos treinos assistimos conversa comigo e atribuiu certa vantagem aos jogadores das equipes de orientadores socioeducativos por eles terem dormido bem à noite, enquanto alguns membros dos times de usuários (acolhidos e conviventes) passaram a noite, ou parte dela, em claro, usando drogas. Sou informado, durante um jogo, da decisão tomada na reunião de preparação deste Intertendas ${ }^{140}$ sobre a distribuição dos troféus de primeiro, segundo e terceiro colocados, melhor jogador e melhor goleiro. Possivelmente, devido ao incidente descrito a seguir, se esqueceu, no final da competição, de premiar jogador e goleiro.

Chegando a semifinal, um orientador socioeducativo questionou os escolhidos entre os acolhidos para compor a equipe adversária a sua, por considerá-la uma composição de jogadores de diversos times de albergados. ${ }^{141}$ Este time teria incorporado os melhores jogadores de outras equipes. Por não ter jogadores reservas, ou por apresentarem pior condicionamento fisico, certas equipes de acolhidos e conviventes ficam visivelmente mais cansadas em campo. A despeito das queixas quanto à composição da equipe, Ronaldo, o goleiro expulso na partida anterior, pôde retornar. Esse mesmo goleiro foi aluno do Programa Nacional de Acesso ao Ensino Técnico e Emprego (Pronatec) ${ }^{142}$ e utilizava sua carteira de estudante para livrar-se de abordagens policiais. Sua camisa de goleiro destoava um pouco do restante do uniforme da equipe por aparentar melhor qualidade e ser mais nova.

140 Intertendas é o nome do campeonato entre equipamentos dedicados ao atendimento da população em situação de rua.

$141 \mathrm{Nem}$ todos os jogadores estão em albergue. Embora, algum jogador possa ter dormido aquela noite na rua, eles possuem algum tipo de vínculo com o sistema, ao menos frequentam a Tenda.

142 O Pronatec é uma iniciativa do Governo Federal, iniciado 2011, para oferecer cursos de educação profissional e tecnológica. 
Existe uma solidariedade dos acolhidos e funcionários entre si e outra de base local, não relacionada à posição no interior do sistema de acolhimento. Assim, o acolhido de determinado albergue pode torcer pela equipe de funcionários deste equipamento, caso não exista um time de acolhidos para quem possa torcer. As preferências parecem guiar-se mais pelos vínculos pessoais que pela categoria.

O time de funcionários da casa, invicto há mais de cinco anos, ficou muito abalado com a derrota e um torcedor desta equipe, também orientador socioeducativo da casa, procurou justificar alegando o cumprimento de plantão na noite anterior, por alguns jogadores de seu time. Quando brinquei dizendo que os jogadores da Barra Funda, acolhidos e conviventes, também poderiam ter farreado por toda noite, ele sorri.

Na semifinal, em uma disputa de bola mais acirrada, Ronaldo tomou as dores do jogador de seu time de acolhidos que sofreu uma falta e avança sobre o orientador socioeducativo que havia tentado, anteriormente, impedi-lo de jogar e com quem havia tido desentendimentos pregressos na Tenda onde este orientador socioeducativo trabalha. Ronaldo foi expulso e precisou ser retirado pelo professor e levado em direção à saída lateral, localizada no fundo da quadra que dá acesso ao refeitório e banheiros. Ele aparentemente não se conformou com a expulsão e retorna carregado pelo professor por outra porta lateral mais próxima da saída do albergue, gritando ameaças ao orientador socioeducativo com quem teve desentendimentos e se dizendo "do crime". Nisto, é ridicularizado pelos outros participantes e segue até a rua, em uma confusão que toma conta de toda quadra e torcida. Um acolhido comenta: "Só porque vende uns papéis lá em cima, pensa que é marginal”. Este mesmo jogador instantes depois iria cobrar uma atitude do professor: "Quem tem que botar disciplina nele é o Luciano".

Instalado o incidente, a primeira decisão tomada por uma freira e um orientador socioeducativo do albergue foi de encer- 
rar o campeonato naquele instante. Em seguida, ouvidos os apelos e verificando-se a grande frustração por parte dos participantes, decidiu-se esperar pelo término daquela partida, já iniciada, com a marcação da final para outra data. Caso o time de orientadores socioeducativos não vencesse a equipe em que Ronaldo jogava quando foi expulso, teriamos uma final entre dois times de acolhidos. O mesmo orientador socioeducativo responsável pela decisão de dar continuidade ao campeonato diz que Ronaldo "tem de saber que isto não pode acontecer" e que "não pode chamar cem pessoas para a briga".

$\mathrm{Na}$ final que acabou ocorrendo regularmente naquele mesmo dia, entre a equipe original de Ronaldo e uma de funcionários, percebo que estes se utilizam de jogadores de outras equipes de orientadores socioeducativos para tentar vencer a partida, procedimento que condenaram nas equipes de acolhidos e conviventes. O resultado da partida é um indiscutível seis a um para a equipe de acolhidos e conviventes, malgrado os esforços e substituições feitas no time adversário.

Para Goffamn e McGinnes (1961) ao término de um encontro, os ex-participantes podem imediatamente formar grupos menores e neles torna-se possivel expressar abertamente assuntos tabus, dando vazão não apenas a enredos segundários, mas a pós-jogos. ${ }^{143} \mathrm{Um}$ choque moral poderia ser invocado em decorrência dos atos impróprios observados por todos, como a atuação do goleiro, mas não é o que ocorre com os acolhidos e conviventes. Após o término do jogo, a discussão gira em torno das jogadas, gols e da alegria e orgulho em terem vencido o campeonato; não em torno do incidente. Sou escalado para tirar as fotos da vitória. Ao levantar a taça e ser fotografado, Maradona, escalado na equipe campeã, fez questão de que a inscrição no troféu "população de rua" saísse na foto: "Mostra aqui, ó, população de rua”. Na opinião do professor, os orien-

143 Nos pós-jogos se dá parte fundamental do trabalho feito pelo professor e será visto mais à frente. 
tadores se "comportaram mais como jogadores de futebol que como orientadores socioeducativos". Ele me confidenciou que teve de se ausentar do jogo por alguns instantes, devido a Ronaldo ter trazido uma arma para vingar-se e ter de ser dissuadido, e comenta: "Ele é 'vapor' e irmão de um 'irmão". ${ }^{144}$

Goffman e McGinnes (1961) tratam os incidentes como eventos ${ }^{145}$ possiveis de ocorrer durante um encontro e capazes de repentinamente aumentar o nível de tensão. Pessoas com estigmas sociais seriam especialmente vulneráveis a provocar contextos nos quais situações constrangedoras poderíam ocorrer. Uma palavra indiscreta seria suficiente para criar mal estar e em qualquer encontro focado, temas oficialmente irrelevantes são sucetiveis de irromper, como antigas rivalidades. Estes temas efetivamente drenam o foco e a atenção dos participantes, trazendo tensão à tona. Sob certas circunstâncias, como as relacionadas ao Intertendas, o indivíduo pode vir a ser inundado por tal fluxo de emoções que não mais consegue fazer uma exibição de conciliação. O evento pelo qual Ronaldo foi afetado, a falta grave, repentinamente o desobrigou de apoiar a interação. Mesmo que momentaneamente, ele deixou de se mobilizar para sustentar um papel expressivo e apropriado ao jogo de futebol e "transbordou". Ao irromper em raiva aberta, ele radicalmente altera seu apoio genérico à interação e se coloca momentaneamente "fora do jogo". (GOFFMAN; MCGINNIS, 1961, p. 55)

Este transbordamento constitui uma quebra no enquadramento e acrescenta um novo elemento distrativo ao contexto do encontro, para Goffman e McGinnes (1961) um transbordamento é geralmente sucetivel de constituir um incidente. Se pensarmos no Intertendas como tendo uma membrana metafórica em torno dele focalizando as preocupações, podemos ver que sua dinâmica está amarrada ao funcionamento da manu-

144 Irmão é o nome dado a quem pertence aos quadros diretivos do PCC.

145 Tanto aqueles provocados de modo intencional quanto os não provocados intencionalmente. 
tenção das fronteiras que o cortam seletivamente de mundos ampliados. Então, podemos começar a perguntar sobre os tipos de componentes do meio social externo ao encontro que irão contrair ou expandir o rol de eventos com que o encontro lida e os tipos de componentes que poderão tornar o encontro mais resiliente ou destruí-lo.

As diferenças de categoria entre funcionários e acolhidos ficam latentes até o momento em que um personagem intermediário, ou mesmo ambíguo como Ronaldo, é absorvido pela raiva. Ambíguo porque goleiro, ambíguo porque "vapor" e não simples usuário, ambíguo porque não dorme em albergues, mas em barraco e é responsável por um "espaço"146 na rua Paim, região central da cidade, mas próxima à Avenida Paulista e aos consumidores de droga mais abastados. Ele não se encontra na condição de acolhido, mas na de convivente.

No momento em que escrevo, Ronaldo se encontra livre, após período preso por tráfico de drogas. Ele possuía uma lista de clientes fixos e chegava a distribuir drogas a domicílio, se locomovendo por táxi pago pelos clientes. Quando pergunto a um seu amigo, semanas após o Intertendas, se Ronaldo teria defensor público, este amigo me responde, com ar de lesa-majestade, ser o advogado "particular". A atividade de "vapor" pode fornecer a estrutura de vida necessária para o uso controlado de drogas. Através do termo "estrutura de vida" que nos referimos a padrões regulares de atividades laborais, recreativas, domésticas e criminais que moldam e constrangem o dia a dia de usuários, assim como suas relações afetivas. (GRUND, 1993) Ronaldo mantém a mesma namorada há mais de cinco anos.

Práticas como "balancear times" (GOFFMAN; MCGINNIS, 1961 , p. 67), aquelas referentes à formação de equipes equi-

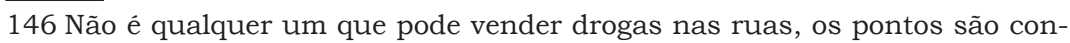
trolados pelo mesmo PCC do qual o irmão de Ronaldo tem uma posição relativamente importante. Quem recebe o espaço deve mantê-lo funcionando. É uma ocupação para todos os dias da semana. 
potentes, de dar desvantagens e limitar participantes a classes de habilidades introduzem maleabilidade suficiente nos materiais do jogo para conseguir que ele seja moldado e aperfeiçoado num modelo melhor adaptado a manter os participantes extasiados. A manipulação das equipes pelos participantes do Intertendas provocou uma controvérsia quanto às regras. Em Fun in Games, os autores apontam como a estrutura do jogo repousa sobre um ordenamento sancionado, base para que obrigações sejam cumpridas e expectativas realizadas. No Intertendas, nem as obrigações foram cumpridas e tão pouco as expectativas foram realizadas pelos jogadores, tanto funcionários quanto acolhidos e conviventes.

Nos equipamentos públicos são cotidianamente ofertadas vagas de emprego e em cursos como o Pronatec, assim como está sempre presente a possibilidade de mudança nas condições de acolhimento em uma progressão de centros de acolhida para hotéis sociais e bolsa aluguel. Neste sentido, o orientador socioeducativo responsável pela oficina de futebol fica atento à evolução do comportamento dentro de quadra, em busca de atributos relevantes externamente capazes de indicar capacidade e disponibilidade para as oportunidades de emprego e moradia. Isto faz da própria organização dos treinos e das convocações para participações em campeonatos instrumentos possibilitadores da máxima exibição dos atributos externamente relevantes e de sua avaliação pelo orientador socioeducativo.

A manipulação das equipes, supracitada, abre possibilidades e impõe limitações às pretensões do professor. Como vimos anteriormente, ele foi questionado por Maradona quanto à escalação das equipes sob sua responsabilidade no Intertendas. Teria privilegiado outro time, desclassificado no decorrer do campeonato, em detrimento do vencedor. Esta acusação objetiva retirar os méritos do técnico e depositá-los integralmente na equipe vencedora, apesar do técnico. O desafio do professor é conseguir balancear o máximo desempenho desejado com as 
individualidades. Para tanto, ele organiza treinamentos com a equipe selecionada para disputar campeonatos em datas separadas das oficinas abertas à participação de todos conviventes da Tenda, na qual o professor presta serviço como orientador socioeducativo.

Certa vez ouvi do professor em um treino: "Aí, Paraná. Você faz seu time". Ele falou em voz alta para todos ouvirem. Posteriormente, o professor nos declarou ser uma forma de provocar o envolvimento no jogo, atribuir responsabilidades. Em outra ocasião ainda, um jogador escalado para a reserva ameaçou sair da equipe caso não entrasse na partida. Esta partida era decisiva em um campeonato "de rua". ${ }^{147}$ Outros casos houveram de jogadores deixarem as equipes por não terem sua vontade de jogar atendida e com isso abandonarem os treinos. Isto inviabiliza o trabalho posterior do professor, como: tirar documentos, matricular em cursos e encaminhar a vagas de trabalho.

Se retornarmos ao assunto dos atributos relevantes externamente e da validade de se demonstrá-los internamente no jogo, poderemos perceber como Ronaldo, justamente por estar em uma posição dúbia, pôde catalisar em si, a oposição entre as categorias. Ele pôde, como convivente, tomar as dores do acolhido agredido em falta desleal por alguém de posição institucionalmente superior, um orientador socioeducativo. Porém, Ronaldo agiu contrariamente às regras de irrelevância que lhe requerem renunciar a ostentar seus atributos sociais externamente relevantes como ser "vapor", ou mesmo "do crime" e quando abertamente introduzidos, seus predicados não solici-

147 Os jogadores diferenciam campeonatos "de rua" e "de Tenda". Os primeiros envolvem times distantes do universo da população de rua. São campeonatos realizados na região central da cidade quando, eventualmente, usa-se a quadra de algum equipamento público para sua realização e por isso, chegam ao conhecimento das equipes estudadas. São particularmente, os campeonatos organizados pela colônia boliviana da cidade de São Paulo, em grande parte moradora da região central. 
tados pelo encontro focado acabaram por ameaçar a membrana ao redor do encontro.

Poderíamos dizer que a aposta de Ronaldo foi alta demais. Caso aceitasse sem reagir o que acreditava serem provocações dos funcionários contra ele, seria igualado aos acolhidos, sem voz e poder devido ao arranjo estrutural no qual estão inseridos. Nestas condições, um participante da partida transborda do encontro para jogar com uma preocupação ansiosa e privada. Para Goffman e McGinnes (1961), um jogador nestas circunstâncias é forçado a levar o jogo excessivamente a sério.

Assim, vale a pena atentarmos para as considerações a respeito da maneira como o jogo pode ser um evento capaz de proporcionar condições à expressão controlada de antagonismos. Porém, esta possibilidade acaba entrando em colapso, caso a excessiva hostilidade inviabilize a expressão deste mesmo antagonismo.

[...] o choque entre times de futebol no campo, pode prover os significados pelos quais o antagonismo entre os dois grupos representados pelos times podem adquirir condições de encontrar-se de maneira controlada e lhes dar expressão. Nós podemos então, prever que, pelo menos, tanto quanto espectadores estiverem preocupados, dois times emergentes do mesmo grupo social podem produzir um conflito que ficará vazio e dois times emergentes de grupos abertamente opostos um ao outro podem provocar incidentes durantes os quais tanta hostilidade flui para dentro da atividade mútua do encontro esportivo até romper a membrana ao seu redor, levando a revoltas, brigas e outros sinais de quebra na ordem. Isto tudo foi sugerido por Max Gluckman em sua discussão do futebol inglês, onde procurou explicar porque as ligas de times podem representar escolas diferentes, cidades e regiões, mas com muito mais dificuldade diferentes grupos religiosos e diferentes classes sociais [...]. (GOFFMAN; MCGINNIS, 1961, p. 71-72, tradução nossa)

Foi preciso um elemento ambíguo, como um goleiro "vapor”, para dar vazão à oposição estrutural entre funcionários 
e acolhidos; entre usuários de drogas declarados e orientadores socioeducativos. No cotidiano dos Centros de Acolhida e de Convivência ocorrem desavenças e conflitos de interesses variados, motivados muitas vezes pela escassez de recursos como vaga para pernoite, ou por regras duras como a proibição de fumar dentro ou nas imediações do equipamento, sob pena de perda da vaga. Regras estas impostas por gestores muitas vezes guiados por suas convicções religiosas, considerando que parte significativa destes equipamentos é gerida por entidades confessionais. Isto faz surgir e perpetua rivalidades entre os membros do quadro de funcionários, principalmente os orientadores socioeducativos, e os acolhidos. Neste sentido, a distância simbólica entre a partida, o campeonato e a opressão diária presente nas interações no interior do Centro de Acolhida não pôde mais ser assegurada quando o incidente rompeu a membrana responsável por controlar o fluxo, para dentro do jogo, de sentimentos de animosidade relevantes externamente.

As regras de transformação permitem a interação em virtude de um disfarce possibilitado pelo jogo. Estas regras são assim definidas pelos autores de Fun in games:

A barreira a bens externamente atribuídos se assemelha mais a um biombo do que a uma parede sólida e, além disso, também transforma e modifica o que passa através dela. Falando mais estritamente, pode-se pensar em regras inibitórias que dizem aos participantes ao que eles não devem prestar atenção e de regras de facilitação que lhes dizem o que podem reconhecer [...] A estas regras de ser, ambas inibitórias e facilitadoras, que nos dizem qual modificação na forma irá ocorrer quando a um padrão externo de bens, é dada expressão dentro do encontro. (GOFFMAN; MCGINNIS, 1961, p. 67, tradução nossa)

Os diferentes papéis, externos e internos ao jogo, podem ter sua introdução pela membrana simbólica a envolver a partida facilitada ou inibida: de orientador socioeducativo para jogador, de acolhido para atacante, de "vapor" para goleiro e de convi- 
vente para torcedor, qualquer que seja o encontro focado, uma partida ou uma roda de crack, ${ }^{148}$ há esse tema dual. O mundo mais amplo precisa ser introduzido, mas de maneira controlada e disfarçada. Um incidente dá margem à quebra da barreira em torno do encontro e há uma inundação do que deveria ser considerado irrelevante ou ao menos, introduzido de modo contido. Indivíduos podem lidar uns com os outros, face a face, porque estão dispostos a respeitar as regras de irrelevância, a deixar fora da interação temas dificeis como as rivalidades pessoais. Dados os perigos da expressão das rivalidades, um disfarce de goleiro ou jogador pode funcionar não tanto como uma maneira de conciliar algo, mas como um caminho para revelar o nivel de competitividade que pode ser tolerado em um jogo. Os encontros são cercados dentro de portões; os próprios meios pelos quais se mantém afastada parte da realidade podem ser os meios pelos quais se pode suportar introduzi-la.

As barreiras impostas pelo enquadramento podem ser por nós apreendidas em seu dinamismo, no uso pelo professor, para melhor se comunicar com seus jogadores, de certas expressões da rua adaptadas pelas regras de transformação à realidade enquadrada do jogo. Assim, ao lado da quadra um jogador pergunta ao professor: "Tem camisa?". Ao que o professor responde: "Tá tendo, tá tendo." Típica maneira de se expressar na rua, onde não se pergunta se alguém tem água, por exemplo, mas se "tá tendo" água. Da mesma forma, mandar um salve a um jogador: "Cadê o Roberto? Salve Roberto!", ou o uso de termos como irmão e primo, associados ao crime organizado como vimos acima: "Joga com essa (camisa) mesmo, José”. Como José não responde: “Joga com essa mesmo, primo". Ainda, outros termos comuns na rua: "Volta, volta, cai pra grupo não [...], calma 'parça' [...], valeu família".O uso destes termos não parece enfraquecer a barreira necessária ao enqua-

$148 \mathrm{Na}$ roda de crack aquilo que deveria permanecer fora da interação e nela adentra, de modo prejudicial, é chamado de "radiação". 
dramento do jogo, mas aparentemente, o torna mais próximo dos jogadores, principalmente se eventualmente, o comparamos com o distanciamento de um treinamento simplesmente baseado nos princípios da educação física.

O fato do campeonato não se restringir apenas a funcionários, ou acolhidos e conviventes é uma maneira de ampliar as fronteiras do encontro e potencialmente confirma e consolida sentimentos relevantes oriundos de outro local. No caso de Ronaldo e o orientador socioeducativo com quem se desentendeu no jogo, a desavença tinha origem anterior e foi renovada nas partidas.

Para Goffman e McGinnes (1961), as racionalizações mais comuns sobre as causas da endogamia social, a regra pela qual apenas iguais são convidados a um encontro social, remetem ao receio de que a mistura de diferentes classes de pessoas faria todos os participantes do encontro focado se sentirem desconfortáveis. Mas devemos atentar também para uma preocupação oposta a esta. Geralmente, conversações e jogos falham não porque os participantes são insuficientemente próximos socialmente, mas porque não são suficientemente distantes. Nos treinos, a absorção pelas partidas costuma ser uma fração do campeonato com mescla de times de categorias distintas de pessoas no sistema de acolhimento. Aquilo que os autores acima denominam como "função de euforia para uma ocasião social” (GOFFMAN; MCGINNIS, 1961, p. 79) reside em algum lugar situado entre a pequena e a grande diferença social, como são as diferenças entre acolhidos e funcionários. No encontro focado absorvente, uma dissolução de certa distância social externamente baseada precisa ser alcançada, com uma penetração das fronteiras do ego. Porém, esta dissolução não necessita ser tão extensa que torne os participantes receosos, ameaçados, ou autoconscientemente preocupados com o que está acontecendo socialmente. Ganhos ou perdas potencialmente muito elevados precisam ser evitados, assim como a possibili- 
dade de haver apenas ganhos ou perdas pouco significativos. Ronaldo tinha muito a perder ao ser confrontado como um mero acolhido, sendo ele "vapor", parente de um "irmão" e não dormir em albergue. Além disto, como mais uma limitação ao enquadramento das partidas e a imposição de barreiras para a realidade externa ao encontro focado, Ronaldo, com apenas 21 anos de idade, tinha sua namorada (desde os 15 anos de idade) participando como torcedora.

\section{A manipulação das regras do jogo}

Nas partidas de futebol do Intertendas ocorre a dramatização dos dilemas da vida de usuários de crack e funcionários das instituições que os abrigam e entretém. Mesmo voltando às antigas condições de "população de rua", uma certeza permanecerá entre os acolhidos: "eles podem vencer no futebol". Porém, obter a vitória pode ter condicionantes para além da qualidade dos times. Na descrição dos membros da sociedade de esquina, mais especificamente do boliche entre os Nortons, feita por Whyte, tomamos conhecimento da variedade de pressões sociais que os jogadores introduzem uns sobre os outros. Estas pressões têm por efeito aproximar o posicionamento relativo das habilidades dos jogadores e seu posicionamento na hierarquia social da panelinha dos amigos de esquina. (WHYTE, 2005) Algo semelhante ocorre no "baba", o futebol praticado nas praias de Salvador e estudado por Jeferson Bacelar (1991). Um time proveniente das áreas de classe média do bairro pesquisado, caso se aventuresse a jogar nas quadras frequentadas após dura conquista, pelos estratos mais proletarizados sairia invariavelmente derrotado do campo, em decorrência das manipulações das regras do jogo e até a violência física exercida pelos líderes do pedaço.

Vimos como as regras do jogo são capazes de influir no sentido de seu enquadramento e passam a governar a execussão dos movimentos no interior de uma situação de jogo. Também 
observamos a necessidade de novos acordos sucessivos sobre elas, após todos os jogadores de dois times empatados terem batido seus pênaltis sem sucesso na tentativa de desempate. Ao persistir a igualdade no resultado, o goleiro Ronaldo chegou até a bater pênaltis seguidos. Em parte dos jogos de treino por nós observados, mais dedicados à diversão e não a preparação para a participação em campeonatos, ${ }^{149}$ a ausência de um juiz permitia aos próprios jogadores manipular as regras do jogo.

Goffman e McGinnes (1961) mencionam a descrição da "pura sociabilidade" feita por Simmel, para situar o advento moderno da universalidade das regras: "Riqueza, posição social, erudição, fama, capacidades excepcionais e méritos, não devem tomar nenhuma parte na sociabilidade". (SIMMEL, 1950 , p. 45-46) Também dizem respeito às regras, as considerações weberianas sobre o capitalismo e seu modo de transcorrer "sem considerar as pessoas", o lema do mercado, assim como, na moderna burocracia, o primado da "igualdade perante a lei". (WEBER, 1946, p. 215-216) Ou, no caso do futebol, perante a regra.

Estas ideias a respeito da universalidade das regras presentes no futebol são mencionadas por Roberto DaMatta ao procurar traçar um paralelo entre o "corpo universal" (DAMATTA, 2006) da modernidade e, recorrendo a Gilberto Freyre, os corpos tradicionais de senhores e escravos, estes, ativos e fortes, enquanto aqueles seriam sedentários. O futebol traria a ideia de um corpo desejado por todos, independente de posição social. Segundo este autor, a sociedade brasileira na época da chegada do futebol no país, na virada do século XIX para o século XX, discutia a ideologia liberal da meritocracia e o futebol seria um esporte meritocrático, por meio do qual um corpo talentoso e capaz de alto desempenho nos campos seria capaz de proporcionar mobilidade social a alguém. Parece que o autor

149 Certa vez na saída de um treino ouvi o seguinte comentário: "É campeonato? É só pra brincar, se divertir". 
prefere não levar em conta o fato de o futebol ter sido profissionalizado no país, apenas em meados dos anos 1930, nem de o destino dos jogadores oriundos da classe trabalhadora, mesmo para aqueles com sucesso dentro de campo, fosse retornar à miséria de onde vieram e, não poucas vezes, em condições ainda piores que seus pares trabalhadores e isto, até poucas décadas atrás. ${ }^{150}$ Mesmo assim, futebol teria sido nosso "mais contundente professor de democracia e igualdade" (DAMATTA, 2006, p. 142) por afirmar os valores capitalistas básicos. Ainda segundo este autor, o individualismo e o igualitarismo presentes na prática futebolística, também viriam ao auxílio da "socialização de uma justiça burguesa e universalista”. (DAMATTA, 2006 , p. 150) O individualismo estaria contido na possibilidade, entre outras, de todos poderem se tornar atletas, embora, esqueça o autor o fato dos jogadores profissionais estarem desde os primórdios do profissionalismo, presos aos clubes como o servos à terra (GALEANO, 1995) por contratos vitalícios, apenas podendo eles, se deslocarem de equipe, com a anuência do time dono de seu passe. ${ }^{151} \mathrm{O}$ próprio Roberto DaMatta reconhece a dificuldade dos imperativos liberais descerem à terra e afirma que "a regra impessoal e igualitária opera até o ponto de não ameaçar os privilégios como outras sociedades com forte ranço tradicional, (com destaque nas relações pessoais, verticalizadas e hierárquicas)". (DAMATTA, 1982, p. 35)

Seria talvez mais cuidadoso se ficássemos com as ideias de Richard Sennet sobre a relação entre regras e igualdade nos esportes: “Jogar requer uma libertação de si mesmo, mas essa liberdade só pode ser criada por meio de regras que estabelece-

150 Citando o autor, "Pois eram disponibilidades que destronavam velhas expectativas, indicando que era o trabalho e o que vinha com ele que iria determinar o lugar de cada indivíduo no sistema". (DAMATTA, 2006, p. 138) O que seria a sociedade escravocrata se não a confirmação desta frase?

151 Esta justiça teria "como procedimento básico a confiança de que tais normas serão aplicadas com isenção por pessoas capazes de controlar seus interesses e simpatias pessoais". (DAMATTA, 2006, p. 150) 
rão uma ficção de igualdade inicial de poder entre os jogadores". (SENNET, 1988, p. 389, grifo nosso) Se olharmos mais atentamente, dentro de campo, nenhum jogador é igual ao outro. Seja em habilidade, em posicionamento, ou em temperamento. Sejam nas suas obrigações decorrentes da posição. Um ala não tem a mesma obrigação de defender o time dos ataques alheios que um pivô, mais sujeito a cometer faltas e ser penalizado ou vitimado pelas regras. O juiz, certamente entra em campo com um conceito a respeito dos jogadores com quem lidará durante a partida. Um imperativo de igualdade quando desce das alturas da ideologia, aparentemente serve mais à instauração da desigualdade e menos a propósitos igualitários.

Os jogos populares de futebol em Salvador, brilhantemente descritos e analisados por Jeferson Bacelar (1991) promovem dois movimentos complementares, primeiro uma inversão da ordem estabelecida pela vitória dos times de jogadores proletarizados sobre os de classe média; e em segundo lugar, um "reforço da coesão coletiva e no exclusivismo grupal". (BACELAR, 1991, p. 110) Estes trabalhadores acostumados às derrotas diárias, têm no "baba" a possibilidade da vitória e da realização pessoal. O prestígio como jogador está não só associado ao desempenho, mas a uma performance de valentia e ao seu passado no bairro. Como não há juiz, o prestígio possibilita a manipulação das regras e influência nos resultados e estes voltam a confirmar a importância da pessoa por uma espécie de retroalimentação. A liderança "não se faz apenas no 'baba' em si, refletindo também o estatuto dos jogadores no bairro e suas relações com a sociedade mais ampla”. (BACELAR, 1991, p. 98) Assim, o "baba" permite a passagem através da barreira em torno do jogo, de alguns privilégios e do prestígio auferido externamente. As regras de irrelevância não se aplicam a valentia provada em embates pelo bairro. Como não há técnico, são os líderes os responsáveis por montar e instruir os times; na ausência de juiz, manipulam as regras e sua capacidade de 
manipulação se encontra ligada a seu estatuto no bairro. Ainda assim, como as regras podem ser manipuladas, mas não modificadas, times de jogadores anônimos conseguem, por vezes, vencer equipes de líderes do bairro.

Vimos acima, como os jogos se constituem em oportunidades de exibição de atributos socialmente valorizados. Porém, o "baba" nos coloca outra dimensão, a do reconhecimento microssocial, nele há a possibilidade de tornar-se centro das atenções, insubstituivel, possuidor de fama, admirado, valorizado e diferenciado no "pedaço". Ou, em nosso caso, na rua, entre os conviventes na Tenda e entre os acolhidos no Centro de Acolhida. Ao se consagrar campeã, a equipe de Ronaldo e Maradona, teve suas fotos com a taça expostas em um mural no centro da Tenda por eles frequentado. Houve reportagem publicada no site da Smads $^{152}$ e semanas depois, uma equipe de reportagem de um programa de esportes, veiculado nacionalmente, foi à Tenda e ao treino, entrevistando o professor e Maradona, além de uma jogadora. ${ }^{153} \mathrm{~A}$ equipe de acolhidos e conviventes venceu o campeonato e certamente, as tentativas de manipulação das regras por parte dos funcionários revelam a importância para estes de evitar uma inversão hierárquica por parte dos derrotados do dia a dia. Apesar do Intertendas não permitir a entrada dos privilégios do cotidiano no enquadramento do jogo e ainda mais, por ter uma sequência de jogos inseridos em um campeonato, com juízes razoavelmente independentes. Este campeonato, porém, pela falta de edições periódicas e por dispor na quadra jogadores inseridos em uma estrutura formalmente hierarquizada, não possui regras de transformação suficientemente elaboradas para permitir a entrada de certos atributos hierárquicos externos. Esta falta de elaboração pode ter levado ao incidente e ao colapso do enquadramento.

152 http: / / www.prefeitura.sp.gov.br/cidade/secretarias/esportes / noticias $/ ? \mathrm{p}=159695$.

153 http:/ / bandnewstv. band.uol.com.br/videos /?v=14831372. 


\section{Os pósjogos}

Ao término das partidas em um treino, o enquadramento relaxa progressivamente e os temas referentes aos jogos vão lentamente arrefecendo e abrindo espaço para outros assuntos. O corpo se encontra em outro estado, após uma série de jogos. A absorção pelo futebol afastou a rotina e estabeleceu seu próprio espaço e tempo. O pós-jogo é momento de relaxamento muscular. Quando em um treino rotineiro, os jogadores se deixam prostrar no chão e podem dividir um cigarro, ou mesmo um baseado, mas também se espera do professor uma espécie de prêmio pelo esforço do grupo em forma de garrafas de refrigerantes e pacotes de bolachas. Enquanto os jogadores estão sentados no chão bebendo e comendo, invariavelmente ele pergunta: "Alguém precisa de alguma coisa?". O sucesso da oficina de futebol em enviar e acompanhar usuários de crack a cursos e novos empregos ${ }^{154}$ está intimamente vinculado ao pós-jogo.

Os jogadores geralmente são recrutados na Tenda e levados até o local do treino, além disto, o professor passa pela Cracolândia quase diariamente e quase sempre encontra algum de seus jogadores e ex-jogadores por lá. É a oportunidade de insistir na volta às oficinas de futebol e lembrar algum "corre" a ser feito em prol do usuário, como buscar seus documentos, matricular em algum curso, entrevista de emprego ou conseguir vaga em albergue e, é claro, lembrar a data do próximo treino. Não existe falta de vagas nos cursos e o mercado de trabalho paulistano, em 2014, absorvia todos os encaminhados; a diferença está no salário e tipo de emprego. Para serviços operacionais menos remunerados, com proventos beirando o

154 Foram cerca de 90 jogadores com seus documentos providenciados e 45 enviados a cursos e vagas de empregos. Isto, somente pelo orientador socioeducativo por nós acompanhado nesta pesquisa. Um ex-jogador chegou a aparecer na propaganda politica do Partido dos Trabalhadores como exemplo de ex-aluno do Pronatec, empregado. Disponivel em: http://www. youtube.com/watch?v=L9nJ6EdJaQg. 
salário mínimo paulista, há vagas para todos os alfabetizados. Empregos mais complexos como mecânico, por exemplo, um curso como os oferecidos pelo Pronatec se faz necessário. Isto não significa, de modo algum, que não existam dificuldades, como, por exemplo, superar os sentimentos de vergonha advindos da carência, vivida por muitos alunos, de vestimenta apropriada para se apresentar em sala de aula. ${ }^{155}$ Será no pós-jogo que o professor irá se informar sobre essas demandas. Pode acontecer também de alguém que "bateu a nave" e faltou a algumas aulas precisar ser demovido da ideia de abandonar o curso, ou emprego.

Neste último caso, os problemas se revelam maiores, dado o despreparo dos departamentos de recursos humanos das empresas demandantes de mão de obra das Tendas em lidar com funcionários usuários de drogas. Como é muito usual "bater a nave" ao receber o primeiro salário, os funcionários são demitidos dentro do período de experiência no emprego, retornando à condição de desempregados, porém, em piores condições devido ao fracasso laboral.

Estes assuntos são tratados com cuidado pelo professor e ele tem essa possibilidade pela proximidade cotidiana e vínculo pessoal estabelecido através das oficinas de futebol. Muitas vezes, o processo se inicia na decisão do participante em retirar seus documentos. A resposta é imediata. De posse de um telefone celular com câmera, o professor procura a primeira parede branca e tira a foto necessária à confecção da carteira de identidade. Caso isso fosse feito na Tenda, demoraria dias ou semanas até se disporem a executar o gasto da foto e revelação. A resposta imediata se mostra fundamental e parte disto é custeada pelo professor e a outra pela Tenda. O trabalho é por

155 Aqueles em situação de rua têm muitas vezes na Tenda, sua porta de entrada para o sistema de acolhimento. Mas, isto não significa, de modo algum, disponibilidade para entrar no prédio de uma universidade e cursar o Pronatec. 
ele executado fora do horário das oficinas, isto é possivel graças a um contrato laboral que lhe dispõe certo número de horas remuneradas para este tipo de atividade. Este comprometimento pode estar ligado ao fato dele ser ex-usuário de crack na região, ex-acolhido e ex-convivente.

As oficinas de futebol possuem data fixa, no entanto, o professor tem contato com os jogadores durante ao menos, 4 dos 5 dias úteis e nos finais de semana com campeonato ou outras atividades. Por outras atividades chamamos os passeios com treino em locais comumente não frequentados pelos jogadores, como as quadras do Parque do Ibirapuera e visitas a estádios de futebol, por exemplo. Estes contatos se dão na Tenda, na Cracolândia e nas ruas do Bairro da Barra Funda e Bom Retiro, principalmente. O processo de recrutamento de novos participantes acontece nestes locais e é por convite informal. Não é necessário nenhum tipo de inscrição ou compromisso com a assiduidade na oficina. Apenas em caso de campeonatos, os jogadores que poderão entrar em campo serão os presentes nos treinos específicos para a disputa.

Os participantes não são obrigados a cessar o uso de drogas antes dos treinos. Houve um caso interessante de atraso no transporte da Tenda para a quadra e os "meninos" permaneceram por algumas horas cheirando solvente Thinner até a chegada do transporte. ${ }^{156}$

Após se saber quem são os jogadores daquela tarde, todos passam a aguardar o transporte do lado de fora da Tenda. A agitação costumava ser grande, havia muita ansiedade para jogar bola. O uniforme esportivo, camisas do time e chuteiras são trazidos de casa, geralmente a pé, pelo professor após ter ele mesmo os ter lavado. Todos na Kombi, saem em velocidade acelerada ao som invariável de músicas de rap com temática

156 O professor se viu em uma situação delicada pelo atraso da Kombi. Misturado à vontade de jogar agregava-se a possibilidade de não poder mais usar a quadra devido ao estado dos participantes. 
baseada na vida de rua, consumo de crack e problemas com a polícia como a música Mágico de $\mathrm{Oz}$ do grupo Racionais MC. ${ }^{157}$ O volume é alto, as curvas são feitas com muita velocidade, principalmente, se tratando de uma Kombi e a conversa flui quase aos gritos. No retorno, após o jogo, a mesma rotina excetuando a parada para consumo de refrigerantes e bolachas. Um ex-jogador da oficina, que iremos chamar de Ronaldo, fez parte de matéria jornalística da Rede Bandeirantes e nesta matéria, ele menciona o pós-jogo.

O crack virou almoço, virou janta, virou café da manhã, virou sobremesa. Virou namorada, virou família, virou tudo [...] Pode parecer até loucura o que vou te falar, meu. Eu olhava assim, pegava a droga. Eu já não tinha nem como mais respirar. Eu falando com você aqui, tava [sic] saindo aquele monte de fumaça do que eu já tinha fumado. Eu fumava a droga e chorando. Quantas vezes eu já fumei droga, colocando ela na boca e chorando. Que eu queria largar ela, mas ela não largava [...]. (CILLO, 2014)

Especificamente sobre as oficinas de futebol, Ronaldo descreve o processo de convite e convencimento.

Então, ele pegou e falou: 'Aí, negão, você não quer jogar uma bola com nós'. Eu falei: 'Ah, vamos lá'. Eu e o pessoal: ele paga um refrigerante, tá e tudo. Para a gente não tinha refrigerante, o nosso dinheiro era droga, droga, droga, droga. Aí eu fui uma vez, fui a segunda e depois o meu tênis estourou, porque só tinha um tênis. Morador de rua vai ter o quê? Só tinha um tênis, aí não fui mais ao futebol. Aí ele olhou pra mim e falou: 'Ô negão, você precisa ocupar seu tempo, não quer jogar bola com nós mais, porque você não faz um curso? Quer ser chefe de almoxarifado? Acho que tem vaga de chefe de almoxarifado, você quer fazer esse curso?' Eu falei: 'Quero, vamos lá'. Aî, quando eu cheguei não tinha, né. Aî, tinha o de ci-

157 Letra do grupo Racionais MC - presença constante nos trajetos entre Tenda e quadra. 
clo de motores a diesel. Aí, foi o que eu [...] me inscreveu, a última vaga. (CILLO, 2014)

O vídeo mostra na sequência, o relato do contratante sobre a iniciativa d e Ronaldo, ex-jogador na oficina de futebol e aluno do Pronatec, em pedir uma vaga de emprego para quando terminasse seu curso. Ao falar sobre seu processo de contratação, o contratado expõe sua visão do significado do novo trabalho para ele: "Quando a gente vê um homem dando uma oportunidade a uma pessoa que também quer ser um homem, assim de verdade, na sociedade, no mercado de trabalho. Tenho seu Milton como um pai, um avô, assim, uma pessoa assim [...] esse é um começo [...] sem fim”. (CILLO, 2014)

O relato acima foi exibido em rede nacional por mais de uma oportunidade e é importante por vários motivos. Primeiro, confirma a importância do ritual do pós-jogo. Geralmente, o pós-jogo consiste da devolução dos uniformes e troca de roupa, saída para a rua e entrada na Kombi com música de temática próxima à realidade fora das quadras, em alto volume. Em seguida, uma parada para o professor comprar refrigerantes e biscoitos, às vezes são fornecidos pela Tenda, mas é raro. O professor retorna ao transporte até nova parada nas proximidades do destino. Todos descem, sentam em sua maioria no chão e se inicia a distribuição dos copos, garrafas e sacos com biscoitos. Caso alguém deixe copos pelo chão, geralmente os participantes sob maior efeito de álcool, (o professor reconhece nunca ter tido problema com uso de crack, só com excesso de álcool) será chamado à atenção, muitas vezes sem sucesso. Finalmente, enquanto todos relaxam sentados, consumindo refrigerantes e bolachas, o professor pode fazer sua pergunta dedicada a iniciar ou dar continuidade ao atendimento de demandas: "Alguém precisa de alguma coisa?". 


\section{Autocontrole, o uso de crack e oficinas de futebol}

Nos jogos de futebol entre usuários de crack, álcool e outras drogas, o abuso destas, antes de uma partida, é a acusação padrão para um mau desempenho. Caso o time saiba de algum jogador que tivesse feito o uso de drogas na noite anterior a uma partida, ou tenha "batido a nave" - expressão usada para recaída no uso - este jogador será seguramente o bode expiatório, principalmente em caso de derrota. Possivelmente, sua má atuação pode até ser menos devida ao seu uso de substâncias psicoativas, ou a uma noite não dormida do que à pressão do grupo condenando seu comportamento. O jogador assíduo aos treinos e cumpridor do resguardo de drogas na véspera, não será reprimido pelas mesmas críticas feitas ao jogador displicente. Cheguei a presenciar acusações enérgicas após uma derrota em um campeonato, contra um jogador, como por exemplo: "Não vem treinar é isso, é isso. É isso que dá não vir treinar." Mais ainda, por parte do goleiro da equipe:

O cara não tem responsabilidade nenhuma, sai de 'rolê' e bate a nave, não quer saber de porra nenhuma de jogo. Ah, vai tomar no cu. Tem que ter responsabilidade. Tem que ganhar rapaz. Sai de sábado pra domingo. ${ }^{158} \mathrm{Tem}$ que ser homem, caralho! Vai bater a nave dia de semana, cara. Eu perco meu aniversário para perder por causa desse 'nóia' do caralho. Ele é meu camarada, tem que falar na cara dele, eu sou homem, entendeu?

Vimos como o envolvimento espontâneo compartilhado em uma atividade mútua coloca os parceiros em algum tipo de solidariedade exclusiva e permite a eles expressar companheirismo, proximidade psíquica e respeito mútuo. A falha em participar de boa vontade pode, em consequência, expressar rejeição aos presentes ou ao contexto. Isto, nos remete à maneira como os encontros focados conseguem prover a base de

158 A partida foi disputada em um domingo pela manhã. 
comunicação para o fluxo de sentimentos entre os participantes e proporcionar a eles compensações corretivas para atos desviantes. (GOFFMAN; MCGINNIS, 1961) As acusações sobre uso de drogas foram feitas durante todos os momentos dificeis da partida, a cada insucesso elas retornavam mais fortes, minando visivelmente a autoconfiança do acusado e acirrando ainda mais os ânimos dos outros jogadores contra ele. O mau desempenho parecia confirmar as expectativas dos demais jogadores sobre como o consumo de drogas prejudica a atuação em campo, contribuindo para reforçar ainda mais as críticas sobre ele. A própria relação tática se modificava e o jogador acusado era agora um desqualificado (GOFFMAN, 1975) dentro de campo, pouco merecedor de receber passes dos demais e assim, diminuindo as chances de ter sua atuação reconhecida pela execussão de boas jogadas e marcação de gols. Se para Whyte (2005), em seu clássico estudo sobre os garotos italianos imigrantes nos EUA do começo do século XX, existe uma correspondência entre a posição da pessoa no grupo, fora das quadras de boliche, e o desempenho dentro delas proporcionado pela pressão do grupo. Pudemos observar uma simetria entre o resguardo de drogas antes das partidas e o desempenho dentro de quadra, porém, este desempenho nos pareceu tão fortemente influenciado pela pressão da equipe de jogadores, quanto o foi na descrição e análise de Whyte.

Vimos acima, como, não obstante o envolvimento de outras pessoas no jogo, a percepção de que algum participante não está espontaneamente envolvido na atividade mútua pode levar a descrédito da identidade imputada a ele como alguém capaz e pronto para imergir-se em um encontro. Pode também enfraquecer para os outros, a confiança em seu envolvimento e sua própria crença na realidade do mundo prescrito.

Ao observar um "baba" jogado em Salvador, Jeferson Bacelar relata um incidente em que uma liderança também usa o consumo de maconha como motivo de acusação, ao discutir 
o desempenho de um jogador durante uma partida: "É melhor você ficar calado, fumando suas 'coisas' prá eu não lhe dar uns murros”. (BACELAR, 1991, p. 100) Semelhante acusação está presente na etnografia de Villela sobre uma "pelada" fluminense, quanto ao uso de maconha e cocaina, porém, o uso da primeira pôde também ser associado ao bom desempenho em campo. $\mathrm{O}$ uso de "brizola" como era chamado o "pó" na época da pesquisa, é motivo para as "zombarias mais pesadas", em tom moralista de acusação sobre seu uso continuado. A maconha, no caso de melhora incomum na atuação em uma partida, ou mesmo em uma jogada é, como dissemos acima, positivamente agregada a este sucesso: “essa é da boa!". (VILLELA, 1997, p. 73)

Para além das acusações quanto ao uso de álcool ou/e drogas, os treinamentos técnicos e táticos semanais promovidos pela oficina de futebol oferecida pela Tenda podem ser vistos como:

[...] esforços para aprimorar a comunicação expressiva corporal entre jogadores. O chamado entrosamento é um ordenamento dos enunciados do corpo, no qual os movimentos são 'sintonizados' a fim de encontrar uma conexão espaço-temporal satisfatória. A interconexão das performances dos jogadores produz uma 'orquestração' do movimento em que a bola faz transitar os 'interlocutores'. (CAVALCANTE, 2011, p. 24-25)

O jogo instala um enquadramento através de regras de irrelevância e transformação capazes de estabelecer uma barreira permeável com o mundo externo. Este enquadramento permite a absorção dos participantes, jogadores ou torcedores nos eventos da partida. Agora, devemos nos perguntar no que consiste esta absorção. Quais são as suas características e como agem na interação dentro da partida. Podemos ver a atuação de um time como uma orquestração, no qual cada ação deve ser harmônica com as outras, com jogadores se comunicando em busca da vitória comum. A comunicação corporal durante 
uma partida de futebol depende da posse ou não da bola; o possuidor intenciona vencer a marcação do adversário, enquanto este age no sentido de quebrar a interação adversária e tomar posse da bola pela marcação. Com ela se busca isolar, impedir a comunicação e induzir a uma arriscada jogada individual, colocando frente a frente marcador e driblador. Um, procura limitar espaços, enquanto outro, pela ambiguidade dos movimentos do drible tenta burlar o adversário. (CAVALCANTE, 2011)

O futebol se massifica no Brasil, a partir dos campos das elites e da intromissão dos gandulas pobres e de jogadores proletários utilizados na ausência de número suficiente de jovens ricos dispostos a jogar. Esta primeira fase de futebol popular, após seu início elitista, pode ser entendida como o tempo do império da malandragem. (CAVALCANTE, 2011) Assim, um habitus malandro baseado na valoração da diversão, experimentação e sedução surge diferente do futebol das elites, ele é marcado por um baixo autocontrole das paixões por parte dos gandulas e vadios a observar os jogos. Enquanto o futebol de elite era caracterizado pelo modelo inglês com chutes para frente e muita correria, o malandro se diferenciava por estar imerso em um contexto periférico das cidades com frouxas redes de interdependência, pressuposto para certa irresponsabilidade e abrindo caminho para a busca da satisfação e experiência corporal. Em contextos sociais diferentes, os modelos de autocontrole também se afastam.

O modelo de autocontrole, o gabarito pelo qual são moldadas as paixões, certamente varia muito de acordo com a função e a posição do indivíduo nessa cadeia [...] variações de intensidade e estabilidade no aparelho de autocontrole que apareçam à primeira vista, muito grandes. (ELIAS, 2001)

A várzea é o lugar do vadio, do gandula, do malandro e de uma rede de sociabilidade aberta para a criatividade; nela, o malandro está à procura de diversão. Seu potencial inventivo está materializado no drible, no chute "folha seca" e no "chute 
bicicleta”. Na atualidade, o futebol amador na cidade de São Paulo ainda é conhecido como futebol de várzea. A região da Barra Funda e Bom Retiro, onde jogam nossos usuários de crack, é a mesma do nascimento de inúmeros clubes de várzea, lá presentes até nossos dias como o popular Corinthians. A rua, assim como a várzea, é lugar de experimentação e criatividade constantes entre moradores das calçadas, baixos de viadutos e os mais diversos tipos de "mocós". ${ }^{159}$

Muitos são os exemplos da criatividade dos usuários de crack nos centros urbanos, particularmente o paulistano. $\mathrm{O}$ cachimbo ou "boris" usado para o consumo do crack se origina de modificações e adaptações a partir da simples folha de alumínio, onde a pedra era queimada e a fumaça sugada com um canudo; passando para o uso da folha de alumínio sobre um copo, porém, agora, perfurada na tampa e acrescida de cinza de cigarro com intuito de evitar o derramamento da pedra derretida para dentro do copo. Desde então, não mais com uso do canudo, mas com uma abertura em uma borda da tampa do copo para permitir aspirar a fumaça. Este arranjo foi mudando até chegar a processo semelhante, porém, em copo de leite fermentado tipo Yakult, com a volta do canudo cuidadosamente introduzido na lateral, para o melhor sorvimento da fumaça. Por outra via, talvez, os usuários tenham adaptado a lata de alumínio amassada ao meio, com pequeno furo na lateral curvada para depósito da pedra sobre cinzas e sorvimento pela abertura da lata destinada a saída do liquido. Este desenvolvimento avançou para alguns cachimbos em curvas dos mais diversos tipos de canos e dos mais variados materiais como PVC e metal, com o alumínio perfurado em uma das extremidades e a outra deixada livre para sorver a fumaça. Finalmente, o cachimbo de fumar crack, aberto aos mais diversos tipos

159 Nome dado aos locais utilizados como moradia como, por exemplo, buracos embaixo de viadutos. 
de adaptações ao corpo e seus múltiplos estados de fadiga e fôlego. Ele faz uma espécie de síntese dos processos criativos anteriores, com o canudo, agora definitivamente estabelecido como "caninho", o frasco de Yakult, a lata e os canos curvados transmutados em "casinha", "fogãozinho" e "curvinha"; todos reunidos à cinza sobre alumínio perfurado.

Não nos parece coincidência ter o jogo de futebol feito tanto sucesso entre os usuários de crack e também parte da população de rua. A quadra ou campo e a rua estão abertos à experimentação, criatividade e busca por diversão. Porém, não apenas de malandragem e diversão é feito o futebol praticado nas Tendas. Aî, também há uma "contaminação disciplinar". (CAVALCANTE, 2011) O futebol com disciplina, no sentido de melhorar a eficiência do jogador e da equipe em jogos de projeção midiática, pelo adestramento do corpo e ordenamento do espaço com atenção para a distribuição dos jogadores em campo, seu posicionamento e ajustamento para máximo rendimento dos movimentos e gestos por meio de atividades codificadas em táticas. (FOUCAULT, 1997) Acabou por transformar o lugar da experiência, marca do futebol malandro, no da tática, como expresso na frase: "Vamos fazer o que o professor pediu para sairmos com a vitória!”. (CAVALCANTE, 2011) A tática visa criar conectividade entre os espaços individuais incorporados a cada jogador pelo treinamento de suas características físicas, técnicas, táticas e psicológicas. ${ }^{160}$ Enfim, uma nova consciência

160 O exemplo abaixo mostra as características a serem desenvolvidas em um Ala no futebol de salão: "Função das Alas: São responsáveis pela armação das jogadas. Devem deslocar-se constantemente, com ou sem bola. $\hat{\mathrm{E}}$ importante ter na equipe sempre um jogador destro e um canhoto em cada ala. Normalmente os alas jogam em posições invertidas (ala direito no lado esquerdo e ala esquerda no lado direito). Os alas devem ser jogadores que utilizam bem os espaços vazios da quadra, com grande percepção das jogadas e precisão nos passes. Devem saber marcar e atacar na mesma proporção, ter excelente controle de bola, dribles e boa finalização são características importantes para os alas. Características físicas: altura ideal de 1,65 à 1,75. Os alas devem ter: agilidade, resistência aeróbia e anaeróbia, coordenação, força e velocidade; Características técnicas: drib- 
para tomada de decisões corretas, identificação de problemas e seleção de habilidades para resolvê-los, ao mesmo tempo em que se cria e nega espaços. (NETO; LEITE, 2010) A consciência desta interdependência gerada pela divisão de funções na quadra suscita o rebaixamento moral da diversão, deixada de lado em nome da equipe interdependente, por dispositivos incorporados para maior autocontrole dos impulsos. Soma-se a isto, o fato de que a medida em que a oficina de futebol passa a ser um treino destinado à participação em campeonatos e, posteriormente, ao campeonato propriamente dito, passa-se de situações sem autoridade central, sem juiz, contando apenas com algumas intervenções do professor, para a monopolização da organização das equipes pelo professor/técnico e pelo também monopólio das decisões quanto à interpretação das regras, concentrado no juiz.

É precisamente a formação dos monopólios que permite a instalação de um mecanismo de 'condicionamento social' graças ao qual cada indivíduo é educado no sentido de um poderoso autocontrole. Aí está a origem do mecanismo de autocontrole individual permanente cujo funcionamento é em parte automático. (ELIAS, 2007, p. 193-4, grifo nosso)

Para além da coerção social, o autocontrole seria uma transformação da economia psíquica pela interiorização das proibições, no sentido de se refrearem os impulsos espontâneos e movimentos imediatos. Segundo Elias, novas relações sociais são capazes de suscitar mudanças nos controles pulsionais no decorrer de transformações específicas nas inter-relações humanas. (ELIAS, 2007) O jogo impõe normas e valores cujos preceitos são obrigatórios para os indivíduos, a não ser pela de-

le, passe, deslocamentos, condução, chute e marcação; Características táticas: armação das jogadas, coberturas, atacar e defender, boa finalização, criatividade e visão de jogo; Características pscicológicas: coragem, combatividade, controle emocional, agressividade, determinação e iniciativa". Disponivel em: <http://pedrocostafutsal.tripod.com/futsal/id27.html>. Acesso em: 14 fev. 2014. 
sistência em participar da equipe, mas como vimos acima, os jogadores que observamos querem jogar e vencer. A racionalidade do jogo se impõe paralelamente a determinadas coerções no sentido do autocontrole das emoções e movimentos. Em um campeonato "de rua", realizado no ano seguinte ao Intertendas, a equipe adversária proveniente de outra Tenda conhecida como Complexo Prates teve um jogador reserva expulso nos instantes iniciais da partida por perguntar ao juiz se ele estaria "chupando o apito" ao não marcar uma pretensa falta em favor de seu time. Enquanto isto, pela outra equipe, o professor advertia para ninguém desrespeitar o juiz. Porém, essa recomendação foi feita mais devido a terem testemunhado a expulsão e menos pela real disposição dos jogadores de sua equipe em ofender o juiz. Como se a coerção externa tivesse sido apropriadamente transformada em coerção interna, em uma racionalidade entendida como modelo conceitual duradouro "da realidade observável nos comportamentos individuais”. (ELIAS, 2001, p. 120)

Um jogador expulso prejudica seu time, posteriormente a expulsão descrita acima, outro jogador da mesma equipe seria expulso por cometer falta grave e seu time terminou a partida com uma derrota por cinco gols a dois. É toda uma rígida rede de interdependência a exigir um autocontrole rigoroso como meio de evitar a ação impulsiva. Esta seguiria a pressão das emoções externas ao jogador, mas internas ao jogo levando a equipe ao fracasso. O jogo de futebol é um enfrentamento entre equipes submetidas à mesma regra e com um juiz responsável por interpretá-la a cada jogada e distribuir as punições. Nele, a luta aberta entre jogadores está fora das possibilidades permitidas pelas regras adotadas e tanto quanto existe uma barreira a enquadrar o jogo e a defendê-lo das influências externas irá se desenvolver através dos treinos e jogos em campeonatos, uma couraça protetora no jogador contra o extravasamento de certas emoções. Esta couraça mantém as emoções sem vazão para o mundo externo e também retém este mundo fora do sujeito. Assim, abre a possibilidade da elevação de "um muro real 
interpondo-se entre eles mesmos e os objetos de sua reflexão". (ELIAS, 2001, p. 279) O futebol abre espaço momentâneo para se separar do mundo e o autocontrole ${ }^{161}$ do jogador inserido na tática da equipe ajuda no soerguimento da couraça necessária à reflexão sobre a realidade externa.

Para compreendermos a extensão das consequências deste envolvimento no jogo se faz necessário revisitar um importante conceito para compreender as flutuações no consumo de drogas, o de estrutura de vida. (GRUND, 1993) Ela se refere a padrões regulares de atividades laborais, recreativos, domésticos e criminais que moldam e constrangem o dia a dia de usuários. São estas atividades regulares (tanto convencionais quanto as relacionadas ao uso de drogas) que estruturam os padrões diários como determinantes chaves da estrutura de vida. Parece lógico incluir os relacionamentos pessoais, compromissos, obrigações, responsabilidades, metas e expectativas. Relacionamentos que são exigentes e simultaneamente tem valor social (afetos) ou econômico (salários) são determinantes igualmente importantes para a estrutura de vida. Contatos regulares com usuários controlados e não usuários são, também de considerável importância, assim como a participação nas estruturas e atividades não motivadas (primariamente) por incentivos relacionados a drogas.

A importância da estrutura de vida é muito claramente demonstrada pela sua ausência, como representado pelo que Grund (1993) chama de junkie de rua. Este tipo de usuário se assemelha com a quase totalidade dos participantes da oficina de futebol, a condição de viver do "corre" incerto e diário, sem uma renda fixa assegurada. Assim como o junk de rua, o usuário de crack sujeito a uma mudança repentina na dispo-

161 A exigência de autocontrole também impõe moderação em face de oponentes, estes não são inimigos absolutos, em determinadas situações de tabela de jogos, o adversário de hoje pode ser a equipe por quem vá se torcer amanhã, caso ele venha enfrentar um time de quem se esteja dependente de sua derrota para obter uma melhor posição nesta tabela. 
nibilidade de drogas - mesmo que seja no sentido de torná-la mais abundante - vê perturbado ou desestabilizado seu padrão diário e estabelecido de atividades (tanto convencionais como relacionado a drogas) e pode levar a uma escalada do uso. ${ }^{162}$

No estudo de Grund (1993) sobre usuários de heroína, foi constatado o fato de um traficante bem-sucedido se vir obrigado a trabalhar sempre em horas fixas, com um time razoável de empregados e manter um registro preciso do balanço financeiro. Devido a isto, não pode, por exemplo, aparecer no ponto de venda em horas irregulares, pois esse comércio varejista para ser bem-sucedido requer estabilidade e continuidade. Tais estipulações estruturam substancialmente a alocação de tempo dos traficantes de sucesso. Assim, a forma e o grau de estrutura de vida são resultado de atividades regulares, relacionamentos, compromissos, responsabilidades e ambições que podem estar ligados ou não às drogas.

A participação nas oficinas de futebol pode ser vista em um contínuo de estrutura de vida, partindo da entrada na oficina e frequência esporádica nos treinos, culminando nas atuações em campeonatos "de rua" com treinos circunscritos à equipe. Neste trajeto, o jogador passa de frequentador ocasional a assíduo nos treinos, comprometendo-se com datas e horários e também passa a estar disponivel em horários e dias fixos na Tenda para seguir ao treino na Kombi. Posteriormente, pode ingressar em equipe participante de "campeonato de Tenda", juntamente com os jogadores ligados aos equipamentos públicos dedicados à população de rua; depois em campeonatos externos e ter contato com equipes fora deste universo. Paralelamente, segue a tirada de documentos, matrícula em cursos e admissão em um emprego remunerado com carteira assinada. A saída da rua iniciada

162 Um interlocutor nos descreveu uma situação de incremento na disponibilidade de crack devido a um "corre" muito bem-sucedido. Segundo ele, nesta ocasião teria sido convidado a fazer uso de uma "rapa", nome dado à "borra" produzida no processo de consumo da droga, proveniente da queima de 80 pedras. 
pelo frequentar da Tenda prossegue com a ida para um centro de acolhida, ou albergue e posteriormente a um Hotel Social ${ }^{163} \mathrm{e}$ repúblicas, ${ }^{164}$ até um possivel reencontro familiar. Em paralelo, vem o maior autocontrole no uso de álcool e drogas, particularmente o crack e a inserção no mercado de trabalho. Vemos isto abaixo, de forma esquematizada:

Figura 42 - Esquema ideal de desenvolvimento da participante nas oficinas de futebol

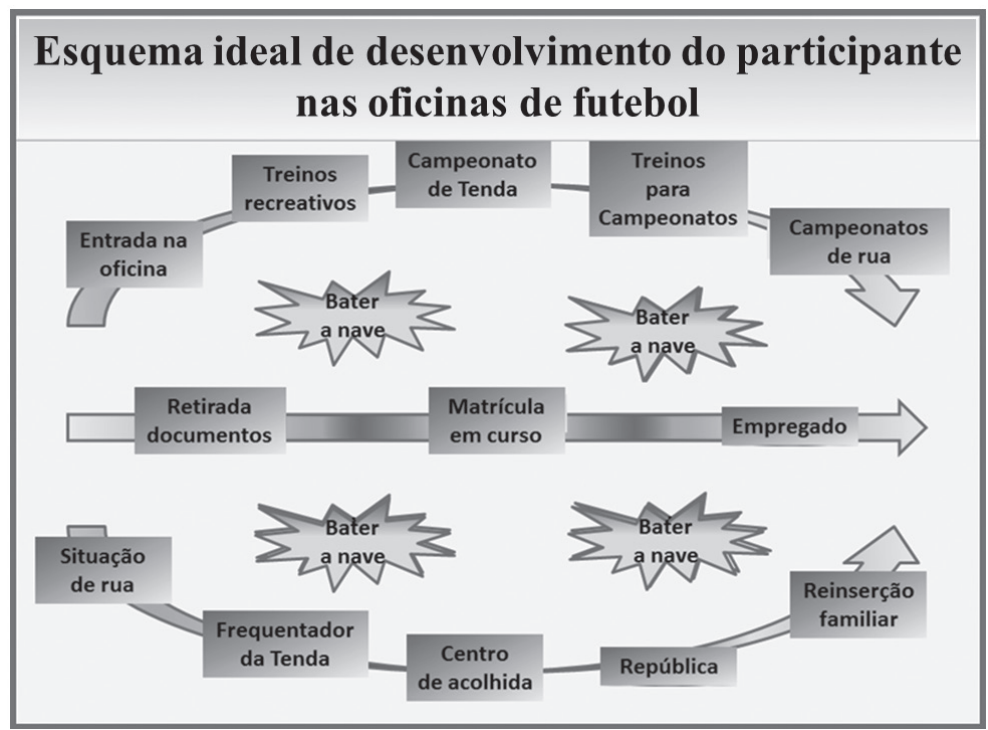

Fonte: Coleção particular do autor

163 "Esta modalidade é ofertada aos usuários independentes e socialmente ativos através de convênio vinculado com hotéis". (SECRETARIA MUNICIPAL DE ASSISTÊNCIA E DESENVOLVIMENTO SOCIAL, 2009, p. 116)

164 "Unidade de acolhida desenvolvida em sistema de cogestão, com capacidade que varia de acordo com o ciclo de vida, gênero, de forma diferenciada para cada faixa etária e diferentes segmentos, com atenção às demandas e necessidades específicas do público a que se destina. Tem como objetivo a garantia da proteção integral para o público atendido, que tenha independência para as atividades da vida diária. Tem como público idoso, pessoas com deficiência, mulheres e homens com vivência de rua". (SECRETARIA MUNICIPAL DE ASSISTÊNCIA E DESENVOLVIMENTO SOCIAL, 2009, p. 120-121) 


\section{De brigas de galos e incidentes entre homens}

As regras de irrelevância são fundamentais para tornar possivel um encontro focado com as características do jogo de futebol, particularmente quando jogado por homens dispostos em hierarquias formalmente estruturadas dentro de equipamentos públicos destinados ao atendimento da população em situação de rua. A inobservância destas regras pode provocar incidentes capazes de desobrigar os participantes a sustentar seu disfarce e a própria interação face a face enquadrada. As "rivalidades do status" (GEERTZ, 1989, p. 291) celebradas na famosa descrição sobre a briga de galos em Bali, não parecem estar disponiveis à celebração nos jogos absorventes entre homens.

Uma briga de galos absorvente, termo que Geertz tira de Fun in Games, é aquela na qual se defrontam "os mais iguais e melhores possiveis" (GEERTZ, 1989, p. 298) e, assim como no jogo entre homens, muito pode estar em questão, "o saber, a estima, a honra, a dignidade, o respeito - em suma, o status" (GEERTZ, 1989, p. 300) que pode ser afirmado ou momentaneamente insultado. Mesmo porque, no caso balinês as somas apostadas não são suficientes para alterar a hierarquia das fortunas pessoais em longo prazo. A hierarquia moral quando posta em questão torna o jogo mais absorvente, são os jogos no qual o status de alguém influente está sob ameaça, os jogos movidos a dinheiro, que não colocam nenhuma posição social em jogo, são menos absorventes. Porém, é pelo dinheiro em vultosas quantias que pode ocorrer "a migração da hierarquia de status balinesa para o corpo da briga de galos". (GEERTZ, 1989, p. 303) Na briga de galos, o prestígio pessoal pode ser reafirmado, celebrado e dramatizado. Os balineses podem brincar com o fogo "sem o risco de se queimar" (GEERTZ, 1989, p. 308) e exibir suas paixões sociais nesta caricatura de guerra, sem alterar a hierarquia. São os sentimentos sobre esta 
hierarquia que podem revelar-se nas lutas, nesta interpretação balinesa de sua própria experiência.

Os jogos por nós observados no Intertendas e campeonatos "de rua" podem desmoronar caso o status pessoal não seja devidamente contido pelas regras de irrelevância. As brigas de galos em Bali eram desfeitas pela ação da polícia, na Barra Funda, os jogos de futebol podem ruir pela ação dos participantes. Isto nos revela uma diferença entre as disputas entre homens e as disputas entre homens através de não humanos. O enquadramento dos animais não depende de seu disfarce, tão pouco de sua vontade. Para ter uma luta de galos absorvente os donos dos animais manipulam apostas em animais mais ou menos identificados com homens. Porém, os galos não podem deixar de apoiar sua interação na briga e abandoná-la, os homens sim, a aposta destes é neles mesmos.

Para concluir este capítulo é importante observar que a retomada do emprego na cidade de São Paulo deu início a um processo de proletarização do lumpesinato, nitidamente percebivel no dia a dia de quem acompanha os serviços direcionados à população de rua, com os quadros de avisos dos equipamentos públicos como Tendas e Centros de Convivência repletos de papéis anunciando vagas de trabalho. Assim como, pelos panfletos distribuídos pelas assistentes sociais com indicações de locais de contratação imediata de mão de obra e nas conversas com acolhidos, conviventes, orientadores socioeducativos e técnicos. Este fator socioeconômico é o pano de fundo estrutural, juntamente com a grande disponibilidade de acesso a cursos de formação profissionalizante gratuitos como o Pronatec, para compreender as consequências das oficinas de futebol sobre seus jogadores, na imensa maioria usuários de crack.

O jogo de futebol fornece a possibilidade de grande absorção em seu interior, pelo enquadramento gerado pelas regras 
de irrelevância. Casos como o incidente com o goleiro Ronaldo são a prova da importância dessas regras. Este envolvimento profundo permite ao professor trabalhar tecnicamente os jogadores aumentando sua interdependência, sintonia e orquestração. A vontade de jogar e de vencer leva à participação em campeonatos e a deslocamentos para realidades fora daquelas próprias ao cotidiano da rua. Ao mesmo tempo, no pós-jogo, o professor oferece uma série de serviços e indica outros rumos a serem seguidos pelos jogadores. Mas, essas aberturas de perspectiva só logram êxito com o acompanhamento do jogador pelo professor. É necessário, assim, abandonar visões ingênuas do esporte como as expressas no lema: "Esporte não é droga. Pratique". Oriundo de campanhas de prevenção ao abuso de drogas da década de 1980. O futebol em si mesmo pode exercer apenas alguma influência sobre o autocontrole do usuário de drogas sobre seu consumo. Para haver adesão às oficinas é fundamental, como declarou o professor, trabalhar na perspectiva de redução de danos onde "ninguém precisa parar de usar". Tal mudança no uso só é possivel no contexto de um ambiente socioeconômico onde o mercado de trabalho se mostra menos excludente, com uma mudança na estrutura de vida do usuário gerada pelos compromissos advindos dos ciclos de treinamentos e jogos, assim como por um acompanhamento individual pelo professor. Sem isto, o esporte pouco poderia influenciar nos padrões de uso. 